\title{
Teknologi og kommerciel udnyttelse
}

\section{Serien som fortælleform}

Serien er en form, der hverken er forbeholdt fjernsyn eller film. Men historien bliver, som nogen engang bemærkede, skrevet af sejrherrerne, og i fortællingens historie har serien (med fjernsyn som en bemærkelsesværdig undtagelse) været den evige taber. Den er blevet fortrængt af andre former for fortælling og er derfor blevet forbigået i de forskellige mediers historie, hvor den har manifesteret sig selv, specielt i litteraturen, i filmen og radioen. I de fleste beretninger bliver det serielle oftest opfattet som irrelevant eller ubetydeligt for et medies udvikling. Et eksempel er den serielle roman, der er blevet degraderet til at have en status af "para-littérature" på fransk eller "Trivialliteratur" på tysk. Filmhistorier nævner den ofte kun i forbigående vendinger enten med et fokus på dens rolle i udviklingen af stjerne-systemet eller som en midlertidig pause i udviklingen af filmens "sande" form, spillefilmen. Det er kun inden for de sidste år, at der er begyndt at komme seriøse historiske beskrivelser af radio, film og romaner udgivet i serieform. Og selvom mange af dem kun i forbifarten nævner de afgørende forbindelser mellem udviklingen og den kommercielle udnyttelse af en ny teknologi og udviklingen af det serielle inden for et bestemt medie, har fastfrysningen af de forskellige discipliner i skoler og uddannelser bidraget til, at akademikere ikke har anerkendt det faktum, at serien, siden det 19. århundrede, har været en dominerende form for fortælling i den vestlige kultur - hvis ikke ligefrem den dominerende.

Vi kan naturligvis alle se, at en serie på ét niveau promoverer sig selv; eller mere præcist, én episode i en serie (eksempelvis Hill St. Blues (Distrikt Hill Street)) promoverer senere episoder af samme serie. Og på et andet niveau har serier traditionelt promoveret produktdifferentiering - hvor aviser eller store radio- eller tv-netværk i store træk tilbyder de samme programmer, hjælper serien med at generere en form for produktloyalitet. Det, jeg mener, er, at et vigtigt aspekt af promoveringsapparatet i forbindelse med en miniserie som eksempelvis The Bourne Identity ${ }^{\mathrm{I}}$ (som i virkeligheden er struktureret som en klassisk føljeton) er den indbyggede præmis, at hvis du nød den, vil du vende tilbage til ABC og se andre programmer udbudt 
hos netværket (bemærk mængden af reklametid $\mathrm{ABC}$ brugte på at promovere egne produkter i løbet af The Bourne Identity-udsendelsen). Det samme gør sig gældende for enhver fjernsynsserie eller serialiseret roman.

Det, jeg gerne vil vise her, er den betydelige rolle, serien har spillet i udviklingen af massemediet. Det er min overbevisning, at seriens primære rolle til stadighed er at udvikle den kommercielle udnyttelse af et specifikt medie. Serien er specielt egnet til at nå dette mål, fordi diskursen mellem medieindustrierne (forlagsvirksomhed, radio, fjernsyn, film) og læseren/lytteren/seeren er det grundlæggende forhold, hvorpå den er funderet. Ved at spore seriens historie, bliver vi i stand til at anerkende, at i takt med at nye medieteknologier introduceres, har den kommercielle udnyttelse vendt sig mod den serielle form for fortælling, netop for at kunne kultivere et loyalt publikum af forbrugere. Dette publikum er således gjort tilgængeligt for og forberedt til at forbruge andre typer tekst stillet til rådighed af det specifikke medie. På denne måde fungerer individuelle serier ikke kun som en platform til at forøge avisernes oplagstal, salget af teaterbilletter, eller stadig dyrere reklamespots, men endnu vigtigere bruges de til at promovere mediet, hvori de optræder. Det forklarer også, hvorfor serier optræder i et givet medie på præcis det tidspunkt, hvor den ægte rival ikke i så høj grad er en anden serie i det samme medie, men et andet medie. For at kunne demonstrere denne pointe, er det nødvendigt at undersøge seriens udvikling i de forskellige massemedier.

I sin elementære form har seriel produktion eksisteret i århundreder. Voluminøse, episodiske og ofte uforbundne fortællinger såsom de indlejrede romancer af den slags, som senere er eksemplificeret ved L’Astrée og Le Grand Cyrus, brød frem med trykpressens udbredelse i det 17. århundrede. Det 18. århundredes trykketeknologi var mere sofistikeret og blev øjeblikkeligt udnyttet kommercielt; men i begyndelsen var trykkeudgifterne høje, grundet den høje pris på selve trykpresserne, den begrænsede produktion af papir, begrænsninger i det antal af kopier de tidlige trykkemetoder kunne producere og beskatning på hvert enkelt af de trykte ark papir. ${ }^{2}$ En måde at reducere omkostningerne var at producere udgaver af store værker (Bibelen, Johnsons og Diderots encyklopædier, såvel som romaner) i hæfter, der var til rådighed for en abonnent portionsvis. Hvert enkelt hæfte af disse tidlige tekster endte typisk midt $i$ et kapitel, midt $i$ et afsnit, eller nogle gange midt $i$ en sætning. ${ }^{3}$ Udgivelse i stor skala blev først en mulighed i det 19. århundrede, med fremkomsten af højhastigheds-trykkemaskiner, udviklingen af stereotypi og, kort derefter, forbedringer i blæk- og papirproduktionen. ${ }^{4}$ Gennemsnittet af trykte sider på Gutenberg-pressen var 150 i timen; i 1846 kunne de damp-drevne trykpresser producere helt op til 8.000 sider i timen. I mellemtiden blev ideen om en billig og bredt distribueret dagspresse undfanget, en udgivelsesform, som blev en direkte konkurrent til bogudgivelse og til de ugentlige aviser, der specialiserede sig i økonomiske og politiske nyheder.

I begyndelsen udkom magasinerne ugentligt, havde en lille distribution og var, på samme måde som bogudgivelse, forholdsvis dyr. I Frankrig kostede et abonnement omkring 80 franc eller mere årligt. (Så sent som år 1900 tjente den gennemsnitlige mandlige arbejder mellem to og seks franc om dagen; den gennemsnitlige kvindelige arbejder 30 franc om måneden: en almindelig tjenestepige i provinsen 
20 franc om måneden.) $)^{5}$ Aviser var derfor, ligesom bøger, forbeholdt de privilegerede. Men i 1836, inspireret af Walters The Times i London, etablerede Emile de Girardin La Presse (i Paris) som en daglig avis med en abonnementspris, der var mindre end halvdelen af konkurrenternes. ${ }^{6}$ Hans plan var at indhente forskellen i omkostninger ved at hæve antallet af abonnementer betydeligt og ved at sælge annonceplads, hvis pris ville afhænge af omfanget af avissalget (fuldstændig ligesom prisen på tv-reklamer i dag er afhængige af seertal).7 Ud over at sænke prisen, afhang Girardins strategi til at tiltrække læsere af, at han kunne levere materiale, som ville appellere til et større læsende publikum. Han valgte at udgive originale romaner i seriel form, som føljetoner, og for at sikre succesen af sin investering ops $\varnothing$ gte han periodens mest succesfulde romanforfatter, Honoré de Balzac.

I oktober 1836 begyndte Girardin at udgive Balzacs la Vieille Fille i daglige uddrag på en fremtrædende plads i bunden af forsiden i La Presse. Selvom den umiddelbare effekt ikke var voldsom, blev seriel udgivelse sammen med lavere abonnementspriser inden for kort tid nærmere reglen end undtagelsen. I 1842 var den serielle udgivelse af fiktion blevet introduceret i alle aviser i Frankrig. ${ }^{8}$ Den kommercielle udnyttelse af højhastigheds-trykpressen og udviklingen i papirproduktionsteknologien havde ført til den billige dagsavis, hvis omkostninger blev udlignet af annoncer og forøget distribution, til dels takket være serialiseret fiktion.

Dette var en afgørende begivenhed for forfattere såvel som forlæggere. Som John Lough bemærker, kunne forfattere for første gang "få en indkomst fra deres værker fra to forskellige kilder, ved først at udgive dem i avisen og efterfølgende i bogform." På den anden hånd kunne redaktører, der stadig sigtede efter et elitært klientel og producerede små, meget dyre udgaver, bruge serien til at teste en bestemt romans potentiale for salg. For forlagsindustrien reducerede de serielle romaner den finansielle risiko ved at placere en roman i et stort og mindre kapitalintensivt offentligt rum, hvor den kunne vise sin kommercielle appel og vække opmærksomhed hos læserne - hvilket også forklarer, hvorfor næsten al fiktion skrevet på det tidspunkt optrådte i seriel form, før den blev udgivet i bogformat. ${ }^{\text {Io }}$

Forlæggere var nu, for første gang nogensinde, i stand til at udnytte en stadigt voksende læsende offentlighed og til at udvikle dens læselyst ved at levere materiale til læserne, der appellerede bredere end nyhederne (hvilket var særligt vigtigt for at kunne kultivere kvindelige læsere, som var blevet trænet i ikke at udtrykke en politisk interesse). Samtidig medførte den serielle produktion også en markant ændring i den udgivne fiktions form. Hvor de tidligste serielle romaner havde en tendens til at være kortere værker, medførte den serielle forms succes stadig længere fiktionsværker. Det tydeligste tidlige eksempel på denne tendens er Eugène Sues Le Mystères de Paris, som optrådte første gang i le Journal des débats, i 1842-43. Udgivelsen af denne roman medførte tusindvis af nye abonnenter og endda optøjer uden for de "cabinets de lecture," hvor folk, som ikke havde råd til at købe avisen, kunne læse med. Det medførte også, at direktøren for den konkurrerende avis le Constitutionnel købte Sues næste roman, le Juif errant, og derved forøgede sit abonnementstal fra 3.600 til omkring $23.000 .{ }^{\text {II }}$

Den uundgåelige kommercielle konkurrence mellem aviserne i perioden førte til en afgørende opdagelse. Salgstallene indikerede, at Balzac var mindre populær 
blandt læserne end Eugène Sue. Selvom begge forfattere behandlede materiale som tiltrak en bred læserskare, særligt fra bourgeoisiet og le petite-bourgeoisie, skyldtes Sues fænomenale popularitet hovedsageligt, at han udnyttede det, der skulle blive en afgørende faktor i den serielle udgivelse: det narrative potentiale i kommercielt bestemte pauser i teksten. Modsat Balzacs fortællinger, som havde en tendens til at slutte hver episode af romanerne på et tidspunkt med et dénouement, ${ }^{\mathrm{I2}}$ udnyttede Sues narrative strategi med stor succes de indbyggede formelle begrænsninger i den serielle udgivelse. Hans fortællinger søger med vilje ikke afslutning; i stedet sluttede han hver episode på et tidspunkt med narrativ spænding, for netop at efterlade sine læsere i suspense. Hvis de ønskede at kende historiens udfald, blev de simpelthen nødt til at købe den næste episode.

Det narrative brud blev således et kendetegn, der var med til at definere det, som er blevet kendt som den ægte føljeton. ${ }^{13}$ Kort sagt iværksætter Sues fortællinger det, Barthes beskriver som den hermeneutiske kode, i én episode, for først at indfri den i en efterfølgende episode. ${ }^{14}$ Senere formmæssige udviklinger i den serielle fortælling har haft en tendens til at fokusere på de forskellige måder, den hermeneutiske kode kan anvendes på. Et nutidigt eksempel er L.A. Law (Advokaterne), hvor hver episode svarer på minimum én fortælletråd - det som Barthes refererer til som et spørgsmål - som blev introduceret i en tidligere episode. Det er grunden til, at programmet altid begynder med prologen "Tidligere i L.A. Law". Herefter introducerer serien selv et eller flere nye spørgsmål, hvoraf kun nogle bliver besvaret i episoden, og bærer de resterende med videre til senere episoder. Således overlapper den narrative udvikling i en episode med tidligere episoder ved at spille på uløste narrative spørgsmål, frem for at udskyde kun ét centralt spørgsmål uendeligt.

Hvis vi et øjeblik vender tilbage til det 19. århundredes udgivelser, kan vi se, at det narrative bruds betydning blev understreget i tidlige udgivelsesspraksisser. I denne periode var det kun muligt at begynde eller forny sit abonnement i juni og december; derfor introducerede forlæggerne ofte, lige når de halvårlige abonnementer var ved at udløbe, en roman af en særlig populær forfatter, netop for at den uforløste narrative spænding ville motivere læserne til at forny deres abonnement. Mere end et halvt århundrede før Pauline var i fare, ${ }^{15}$ blev cliff-hangeren således født ud af den serielle udgivelse, som et resultat af det kommercielle krav om at opdele en længere fortælling og på samme tid vende opdelingen til en kommerciel fordel ved at motivere læserne til at fortsætte med at forbruge et medies produkt regelmæssigt.

Op imod denne form for fortællestruktur, som udgør den ægte føljeton, kan vi stille to andre beslægtede former. Den første er den serielle udgivelse af længere fortællinger i relativt selvstændige episoder eller kapitler. I denne slags udgivelse, som eksemplificeres ved Balzacs praksis, er fortællingens struktur reelt upåvirket af dens fremstillingsform. Den anden praksis indebærer produktionen af en række af uafhængige, afsluttede episoder som forbinder sig gennem brugen af tilbagevendende karakterer og en grundlæggende diegetisk situation, men ikke i form af en overordnet fortællestruktur. Sherlock Holmes, Fantômas og de fleste sitcoms er eksempler på denne praksis, som er blevet overleveret til os som den ægte serie, en videreudvikling af et kommercielt og/eller populært svar til karakterer portrætteret i korte fiktionsværker. 
Lad os tage en tur over på den anden side af Atlanten og se på det, der for vores undersøgelse er en afgørende hændelse i amerikansk avishistorie, og som førte til udviklingen af både avis-tegneserien og filmføljetonen. Omkring århundredeskiftet var konkurrencen mellem rivaliserende aviser i New York voldsom, særligt mellem de to dominerende aviser, Joseph Pulitzers New York World og James Gordon-Bennetts New York Herald. I et fors $\varnothing g$ på at øge distributionen begyndte Pulitzer i 1885 at udgive et søndagstillæg, hvilket medførte en stigning i oplagstal for The World til 300.000 inden for en periode på syv år. ${ }^{16}$ Da en anden konkurrent, F. Duke, i 1890 blev en del af markedet med The New York Recorder, besluttede han at bruge den nyligt udviklede farvetrykteknologi for derved at kunne konkurrere direkte med The World og The Herald. Pulitzer fulgte øjeblikkelig trop. I 1894 begyndte en af de kunstnere, der stod for tegningerne hos Pulitzer, Richard Outcault, at tegne en serie, som han kaldte for "Hogan's Alley", som handlede om en gruppe karikaturers forskellige eventyr. En af karaktererne, kendt som "The Yellow Kid", fordi hans tøj var klart gult, blev utroligt populær blandt læserne. ${ }^{17}$

Så ankom William Randolph Hearst, som på det tidspunkt kørte The San Francisco Examiner. Da Hearst bevægede sig ind på markedet i New York ved at købe den mindre Morning Journal, lancerede han også et søndagstillæg i farver, Humorist, og begyndte at publicere James Swinnertons tegninger (Little Bears and Tigers). Han gennemskuede, at nøglen til kommerciel dominans over markedet i New York var farvebilleder som dem, Outcault producerede for Pulitzer, og hyrede Outcault fra The World. Outcault flyttede til Hearsts American Humorist i 1896, hvor han videreudviklede "Hogan's Alley" og, ved at fokusere på The Yellow Kids' eventyr, skabte den første rigtige tegneserie. Effekten var så stor, at The Morning Journal hurtigt blev den største amerikanske avis, med et oplag på mere end halvanden million eksemplarer i $1907 . .^{18}$ (Det er i øvrigt denne figur, der lægger navn til begrebet "yellow journalism"). Fra dette øjeblik udviklede alle større aviser deres egen tegneseriestribe. Outcault begyndte at lave Buster Brown, mens en anden Hearst-tegner, Carl Briggs, introducerede den ægte føljeton til tegneseriegenren med Piper Clerk, som afsluttede hver stribe i suspense. Bud Fischer adopterede det i Mutt and Jeff, som første gang optrådte i Hearsts San Francisco Chronicle i 1907.

Pointen er, at brugen af billeder til at illustrere en fortælling, havde eksisteret i århundreder. Træudskæringer havde eksisteret siden slutningen af det 15. århundrede, images d'Epinal var på mode i 1820'erne, ${ }^{19}$ og Topffers billedhistorier blev lovprist af Goethe i det efterfølgende årti. Alligevel var det først, da avisredaktørerne begyndte at udnytte en ny teknologi - højhastigheds-farvetryk - til at øge oplagene, at tegneseriestriben opstod. Historien er på mange måder den samme for filmføljetonen, og nok engang involverer den Hearst.

Et par år senere besluttede Hearst sig for at rykke ind på markedet i Chicago og hans Evening American kom i skarp konkurrence med Cyrus McCormicks Chicago Tribune. I 1912 bragte forsiden af Hearsts tillæg, The Ladies World, en kunstners gengivelse af den ideelle amerikanske kvinde. Edward McManus, magasinets direktør, fandt på at lave en række af korte film, som skulle vise hendes eventyr. Resultatet var filmserien What Happened to Mary?, produceret af the Edison Company i 1912. 
Det efterfølgende år blev den fulgt op af Who Will Marry Mary? Hver historie optrådte samtidig i The Ladies World i seriel form.

På samme tid som disse begivenheder udfoldede sig, forlod en række ledende medarbejdere i Chicago Hearst; og McCormick hørte om Mary-serien, mens den stadig var ved at blive produceret. En af afhopperne, Walter Howey, var fascineret af ideen om en filmserie og helt klar over det øgede salg af The Ladies World. Men da han ikke var tilfreds med ideen om en serie af uafhængige film, med en række usammenhængende begivenheder, fik Howey den ide at lave en lang filmfortælling i ugentlige afsnit, hvor hvert enkelt afsnit ville levere materiale til syv dele af historien, der skulle trykkes i ugens $1 \varnothing b$ forud for filmens premiere. Det første resultat, Selig-produktionen Adventures of Kathlyn fra 1913, skaffede 50.000 nye læsere til The Tribune og etablerede filmseriens popularitet. ${ }^{21}$

Men Hearst lod sig ikke sådan udkonkurrere. Chefen for Hearsts King Features Syndicate, Moses Konigsberg, hørte om McCormicks planer gennem Selig, som han allerede samarbejdede med, og advarede Hearst om den alvorlige situation. Hearst købte derfor rettighederne til en film, der allerede var i produktion hos Edison, The Active Life of Dolly of the Dailies (1914), og begyndte at serialisere historien i sine aviser. Samtidig begyndte Hearst at producere føljetonen Lucile Love, Girl of Mystery og senere samme år The Perils of Pauline (Paulines eventyr), den første føljeton produceret af Pathé, som havde tidens mest populære skuespillerinde Pearl White i hovedrollen. Da disse filmserier blev importeret til Frankrig, blev de starten på en lignende mode, som blandt andet medførte produktionen af Feuillades Fantômas.

Endnu engang ser vi en medieteknologi, hvis kommercielle udnyttelse er knyttet til introduktionen af serien som fortælleform. Allerede i begyndelsen af 1900-tallet havde filmen etableret sig som et medie, der kunne bruges kommercielt. Føljetonen hjalp, sammen med Griffiths eksperimenter med fortælleformer hos Biograph, filmen med at bryde løs fra de kortere underholdningsformater som trickfilmen, enkle komedier eller dramatiske episoder eller panoramaet. Lige så afgørende er det, at føljetonen hjalp med at skabe et forbrugerpublikum, som ikke kun gik i biografen for at opleve en (hurtigt udtømt) nyhed, men snarere et publikum, der var villig til jævnligt at vende tilbage til biografen for at forbruge fortællinger. Således blev traditionen for "Saturday Matinee at the Bijou"22 født. William Cline noterer sig, at føljetoner

4 voksede i popularitet og blev en grundpille for biograferne i årene før og efter 1920, da pionererne inden for spillefilm eksperimenterede og udviklede ideer, teknikker og emner som ville være attraktive for det voksende marked. Biografernes bagmænd følte, at selv hvis de havde en spillefilm med tvivlsom tiltrækningskraft på plakaten, ville dagen måske blive reddet af kundernes vedholdende interesse i en god, skarp, actionfyldt serie. ${ }^{23}$

Det var først senere, omkring 1930, at filmføljetonen blev degraderet til kun at have status som en "ekstra attraktion" ved siden af hovedattraktionen, selvom den fortsatte et stykke ind i 1940'erne ved parasitært at låne fra den succes tegneseriestriber, som Prince Valiant, Flash Gordon (da. Jens Lyn) og Buck Rogers og radioserier som The Lone Ranger havde. 
Men hvorfor begyndte det at gå tilbage for filmføljetonen i 1930? På den ene side var det årtiet, hvor spillefilmen blev den gængse fortælleform i biografen, den som ingen satte spørgsmålstegn ved. Men vigtigere, og ikke helt tilfældigt, var dette også perioden, hvor filmen blev tilføjet lyd. Og det på præcis samme tid som radio, der på det tidspunkt var den nyeste teknologi, som kunne udnyttes kommercielt, begyndte at producere sine egne føljetoner. Radioen var blevet opfundet før Første Verdenskrig og brugt flittigt til privat kommunikation. Men helt frem til 1929 var radioens udviklere sene til at opdage radioens potentiale som massekommunikation. Så sent som 1916 beskrev David Sarnoff, der senere blev leder af RCA, ${ }^{24}$ en strategi, der skulle sikre, at radioen blev "et apparat, der, på samme måde som klaveret eller fotografiet, var at finde i ethvert hjem." ${ }^{25}$ Men Sarnoff og andre manglede stadig at overveje føljetonen. Og det spørgsmål, der stadig manglede svar, var, hvordan man kunne indhente de enorme omkostninger forbundet med radioens udvikling.

Efter en indledende periode, hvor næsten alt tænkeligt blev sendt, men i begrænset omfang, opstod radioføljetonen som et af de tidligste eksempler på regelmæssigt programsat radio (og den blev hurtigt knyttet til reklamesalg). Den første radioserie, Amos 'n' Andy, blev produceret i 1929. Radioproducenterne var helt klar over, at føljetonerne havde været et effektivt lokkemiddel i forhold til biografgængere og fulgte derfor biografens eksempel med at lokke lytterne med dramatiske føljetoner eller serier som The Shadow (Skyggen) og The Lone Ranger. Sammen med varieté, musik og komik bidrog føljetoner og serier til den enorme succes, radioen oplevede op gennem 1940'erne.

Men i 1946-47 dukkede en ny teknologi op, fjernsynet. Der var to øjeblikkelige konsekvenser: Næsten alt talent forlod radioen til fordel for det nye medie, og den indtjente profit fra radioen blev brugt til at understøtte fjernsynets enorme udviklings- og produktionsomkostninger (de fleste tv-stationer blev etablereret af radionetværk som NBC og ABC). Stillet over for denne konkurrence reagerede de, der lavede radio, ved at forlade de traditionelle produktionsmetoder til fordel for en ny og billigere tilgang, og for-optagede musikprogrammer erstattede med tiden næsten alle former for liveproduktion inklusiv føljetonen. ${ }^{26}$

Endnu engang ser vi en medieteknologi, der havde eksisteret i en årrække, men hvis masseappel først blev udnyttet, da den introducerede føljetoner og serier i direkte konkurrence med et andet medie. Sammen med andre former for underholdning tillod føljetonen, at fjernsyn kunne finde fodfæste som massemedie ved at udvide dets programplanlægning og lade andet end hundeshows, rulleskøjteløb og samsending af radioprogrammer indgå (og i processen medføre en total forandring af dets nærmeste konkurrent, radioen).

Og det er på tv, at serier og føljetoner fortsætter, selvom nutidens programlægning synes at sløre den teoretiske skelnen mellem den ægte føljeton og den ægte serie. Men i stedet for at gøre rede for de seneste udviklinger inden for fjernsyn (nogle af dem har jeg allerede nævnt), vil jeg gerne pointere, at der er en moderne analog til det 19. århundredes avisabonnement-strategi, som jeg beskrev ovenfor. Det skal forstås på den måde, at det kommercielle fjernsyns sæson på mange måder fungerer ligesom det 19. århundredes abonnementskalender. På samme måde som abonnementer dengang kan vores serier i dag "fornyes" eller "droppes". Men mere 
væsentligt, i flere af serierne finder vi en tradition for at skabe en uforløst spænding i den sidste episode af en sæson. Eksempelvis rejser sidste episode i 1986-87-sæsonen af Moonlighting (De Heldige Helte) mindst to spørgsmål: Om en eller to af de centrale karakterer vender tilbage til detektivbureauet, og om deres forhold vil ændre sig i den periode, hvor serien holder pause. Men det mest berømte eksempel på denne teknik er selvfølgelig den kontrovers, der opstod for et par år siden i Dallas: "Hvem skød J.R.?" På samme måde, men i en mindre skala, skaber sæbeoperaer i fjernsynet ofte en uforløst spænding i fredagens episode for at motivere seerne til at vende tilbage efter weekendens pause. På en endnu mindre skala, inden for en enkelt episode, bruger tv-serier indimellem teknikken med dramatiske brud til at fastholde seerne, til vi kommer om på den anden side af reklamepauserne. I alle disse tilfælde er den hermeneutiske kode i brug for at kunne fastholde læserens/seerens interesse hen over en periode uden forbrug, netop for at motivere forbrugeren til at vende tilbage til produktet, når det igen bliver tilgængeligt. Helt enkelt kan det serielle karakteriseres som en form for fortælling, hvor tilfredsstillelsen udskydes evigt.

Det synes unødvendigt at understrege, at det serielle, sammen med nyhedsudsendelser og game shows, er en grundpille i kommercielt fjernsyn. Den måske tydeligste nutidige manifestation af den ægte føljeton er "miniserien", som i virkeligheden er en misvisende betegnelse, da de alle er ægte føljetoner, der står i gæld til den fortælleform, der oprindeligt blev udviklet i det 19. århundredes fiktion. ABCs America, for eksempel, er en klassisk føljeton, endda med en cliffhanger i hver episode, efterfulgt af det klassiske føljeton-slogan, "fortsættelse følger." At tv-netværkene bruger miniserien til at $\varnothing$ ge ratings gennem "sweeps"-perioderne ${ }^{27}$ understreger blot, hvor langt de vil gå for primært at kultivere et publikum af forbrugere, på samme måde som det var tilfældet med den serielle roman.

Men lad os nu se på de nutidige mediepraksisser. Film i dag er også, efter en periode, hvor de forlod formen, vendt tilbage til føljetonen. Flere film udgør ægte serier, eksempelvis James Bond-filmene. Men et overraskende antal af ægte føljetoner bliver stadig produceret, såsom Star Wars-sagaen og Star Trek-filmene. Og tilmed vender producere, på grund af det usikre forretningsklima i Hollywood og de stigende omkostninger ved filmproduktion, (alt for) ofte tilbage til en etableret form, hvor de kan udnytte et allerede defineret publikum ved at producere efterfølgere til succesfulde film. Man kunne diskutere en nedre grænse for antallet af episoder, der er nødvendige for at udgøre en føljeton; men siden en sequel per definition udvider en tidligere eksisterende teksts diegetiske situation, bruges en række film-sequels til at transformere den originale tekst til en episode i en ægte føljeton, som eksempelvis Alien (1979 (Alien - Den 8. Passager)) og Aliens (1986 (Aliens - det endelige opgør)). Nogle sequels sætter endda spørgsmålstegn ved slutningen på et originalt manuskript, som vi ser det med Jewel of the Nile (1985 (Nilens juvel)), som indleder med at demonstrere, at den traditionelle "lykkelige slutning" i Romancing the Stone (1984 (Nu går den vilde skattejagt)) langt fra var endegyldig.

Kort sagt, føljetonen lever i bedste velgående inden for flere forskellige medier. Min tese om, at føljetonen dukker op i et medie på præcist det tidspunkt, hvor den rigtige rival ikke så meget er en anden føljeton i det samme medie, som det er et 
andet medie, synes at blive bekræftet af fremkomsten af Tanner '88 på HBO, Max Headroom på Cinemax, og Berlin Alexanderplatz på Bravo. Men det er for tidligt at spå, om det udgør en ægte trussel for netværks-tv.

Som den foregående diskussion antyder, har den serielle form for fortælling konsekvent været forbundet til den kapitalistiske udnyttelse af medieteknologier, og som en konsekvens heraf har hver teknologi udviklet sig til et vigtigt medie for massekommunikation. En af grundene til denne kommercielle succes er, at det serielle kultiverer en pålidelig gruppe af forbrugere, som bliver tilgængelige og forberedte til at forbruge andre typer af tekst leveret af netop det medie. I et socialt system, som konstant udsætter begær for at promovere fortsat forbrug, og hvis massemedier står som en central form for kommercielt foretagende, fremstår det serielle som en ideel form for narrativ repræsentation under kapitalismen.

Copyright (c) 1988 Roger Hagedorn. Artiklen optrådte første gang i det nu hedengangne tidsskrift Wide Angle (vol. 10, \#4) og er oversat med tilladelse fra forfatteren.

Redaktionel note: I bestræbelsen på at lægge os så tæt op ad originalen som muligt, har vi valgt at bibeholde forlæggets referencepraksis.

Oversat af Lene Baggesgaard

\section{Noter}

I Miniserie i to dele sendt på $\mathrm{ABC}$ i 1988. O.a.

2 Claude Ballanger et al., Histoire générale de la presse française, Vol. 2 (Paris: Presses Universitaires de France, 1969), pp. 13-26.

3 Robert L. Patten, "Pickwick Papers and the Development of Serial Fiction," Rice University Studies 61:1 (Winter 1975), p. 52. Se også R.M. Wiles, Serial Publication in England Before 1750 (New York: Cambridge, 1957), p. 289.

4 Bellanger, pp. 20-25. Se også John Lough, Writer and Public in France (Oxford. Clarendon, 1978), p. 289.

5 Anne-Marie Thiesse, Le Roman du quotidien (Paris: Chemin Vert, 1984), p. 16.

6 Ibid., p. 16.

7 Girardin bemærkede i det første nummer af La Presse, at "når prisen på reklamer har indflydelse på antallet af abonnementer, bliver vi nødt til at reducere abonnementsprisen til et minimum for at hæve antallet af abonnementer til et maksimum.....Det er reklamerne, der betaler for aviserne." Se Lough, pp. 294-295.

8 René Guise, “Balzac et le roman Feuilleton," L’Année Balzacienne (1964), p. 285.

9 Lough, p. 295.

Io Guise, p. 285.

II Thiesse, p. 84.

I2 Plottets opløsning eller afsløring. O.a.

I3 Robert Hagedorn skelner herfra mellem the serial, the series, the serial proper og the series proper. Jeg oversætter herfra rimeligt konsekvent serial som føljeton, series som serie og proper som ægte, men begreberne er altså på engelsk nært knyttet til hinanden - og til begrebet seriel, serial. O.a. 
I4 Se Roland Barthes, $S / Z$, trans. Richard Miller (New York: Hill and Wang, 1974).

I5 I The Perils of Pauline, 1914, som nævnes senere i artiklen. O.a.

I6 Jean Mitry, Histoire du cinéma, Vol. 2 (Paris: Editions Universitaires, 1969), p. 18.

I7 Min diskussion af denne periode i tegneseriens historie beror på Mitry, pp. 17-20, og Pierre Couperie et al. A History of the Comic Strip, trans. Eileen B. Hennessy (New York: Crown, 1968), pp. 19-29.

I8 Mitry, p. 19.

I9 Farverige tryk om populære emner opkaldt efter trykkehuset Imagerie d’Épinal. O.a.

20 Mitry, pp. 22-24. Se også Benjamin B. Hampton, History of the American Film Industry From its Beginning to 1931 (New York: A.S. Barnes, n.d.), pp. 158-159.

2I Anthony Slide, Early American Cinema (New York: A.S. Barnes, n.d.), pp. 158-159.

22 Matinée at the Bijou var en tv-serie på PBS-netværket, som mellem 1980 og 1985 forsøgte at genskabe den klassiske biografoplevelse fra 1920'erne med en sammensætning af korte film og føljetoner. O.a.

23 William C. Cline, In The Nick of Time: Motion Picture Sound Serials (Jefferson, N.C. Mc Farland, 1984), p. 1

24 Radio Corporation of America, en førende producent af radioer og initiativtager til det første landsdækkende radionetværk National Broadcasting Company (NBC). O.a.

25 Girard Chester et al, Television and Radio (New York: Meredith, 1971), p.1.

26 Se Charles A. Stepmann, Radio, Television and Society (New York: Oxford, 1950), pp. 3-14, og V. Jackson Smith, Programming for Radio and Television, rev. Ed. (Washington, D.C. University Press of America, 1983), pp. 5-32.

27 I store dele af USA gennemføres målinger af seertal kaldet sweeps kun i månederne februar, maj, juli og november. O.a. 